\title{
OBITUARY
}

\section{NORMAN MCOMISH DOTT, I897-I973}

Professor Emeritus Norman McOmish DotT, C.B.E., M.B., CH.B., F.R.C.S.(ED), HON.M.D.(EDIN.UNIV.), HON.F.R.C.P.\&S.CANADA, F.R.S.E., and Honorary Member of the International Medical Society of Paraplegia, died suddenly in Edinburgh on 1o December 1973. He was 76.

A man destined to become a world pioneer of neurological surgery, he had a personal and professional life from which many lessons may be learned. Norman Dott became an apprentice joiner and engineer when he left school, but in 1913 he sustained a severe injury to his left hip, and whilst undergoing prolonged hospital treatment he realised that he was fascinated and intrigued by medicine and he decided to become a medical student. He graduated from the Edinburgh University Medical School in 1919, and showed an early inclination towards surgery, to begin with paediatric surgery. In addition he carried out original laboratory research in the Department of Physiology of Sir Edward Sharpey Shaeffer, and it was his studies on the pituitary gland that helped him to gain a Rockefeller Travelling Fellowship, becoming a junior associate in Neurological Surgery in the Peter Bent Brigham Hospital in Boston, Massachusetts, under the famous Dr Harvey Cushing in 1923 to I924. This decided Norman Dott's future career as a specialist in Surgical Neurology, but as is the case with all pioneers, he had to overcome many prejudices and difficulties. With great determination he established Surgical Neurology as a specialty and in I93 I was appointed Neurological Surgeon to the Royal Infirmary of Edinburgh, and in the following year lecturer in Neurological Surgery in the University of Edinburgh. Subsequently he consolidated this new specialty and elaborated and developed it so that he gradually established the most comprehensive Department of Surgical Neurology in the United Kingdom.

During the 1939-45 World War he founded a special Neurotraumatology Unit in Bangour Hospital, near Edinburgh, and one aspect of this was the Spinal Injury wards. Patients with acute spinal injuries were brought by ambulance or were flown to this unit from many parts of the world. Subsequently patients with non-traumatic spinal injuries were also received in this acute ward, usually on the day that the spinal paralysis had occurred, and they were intensively studied and appropriate treatment was carried out. Norman Dott arranged that doctors from the Scottish Government Office and from the Armed Services should visit the National Spinal Injuries Unit at Stoke Mandeville Hospital and have discussions with Dr Ludwig Guttmann, so that we in Edinburgh could learn directly about the wonderful pioneering work being carried out there, and could introduce new ideas to Edinburgh. Dott said that 'permanent total paralysis continued with an almost uniformly fatal prognosis until the I940s when the public conscience was stirred about the condition and future of young war-injured spinal paralysis patients. The formerly fatal complications became better understood and treated. They could now survive in good health. Wheelchairs were improved, personal motorised transport was provided and economic employment was sympathetically considered. Gradually these medical and social advances spread to become standard practice-eventually reaching spina bifida children, with a remarkable effect on their survival and potentiality.' In Edenhall Ministry of Pensions 
Hospital, near Edinburgh, Sir Walter Mercer and Norman Dott in the early I950's established a Spinal Paralysis Unit which now plays a major part in the Spinal Paralysis Services in Scotland.

Norman Dott had many interests and made a large number of original contributions to his specialty of surgical neurology, including innovations in the field of Spinal Paralysis. In 1947 he introduced and developed the anterolateral operation for Pott's (tuberculous) paraplegia; he also developed new procedures for the management of intractable pain; and he illustrated to a high degree the necessity for 'continuity of patient care' and this of course included the full rehabilitation of spinal paralysed patients.

Over the years he attracted visitors and indeed also patients from every part of the world, and many high honours were bestowed upon him. He was a founder member of the Society of British Neurological Surgeons and was President from I939 to I945; he was a member of the General Medical Council, and from I956 to I967 he was Vice-President of the Royal College of Surgeons of Edinburgh.

$\mathrm{He}$ was actively involved in several voluntary medical organisations, thus for example he was Honorary President of the Scottish Paraplegic Association, Honorary President of the Scottish Spina Bifida Association and President of the Scottish Association of Occupational Therapy.

His own disabilities appeared to stimulate a special desire in him to care for the physically disabled, and they did not deter him from taking a very active part in his favourite sport, that of fishing-often waist-high in swiftly running rivers.

He much preferred apprenticeship training to didactic teaching, and he was a stimulating conversationalist, a great friend of young people during their medical training, and a wise counsellor and adviser for those who, quite often even though senior, still sought his opinion. At all times he demanded the highest possible standards from every member of his staff. His main interest was always his patients, thus he characteristically concluded in his remarks, when he was the distinguished guest of the Congress of Neurological Surgeons in 1968 in Toronto, 'When we contemplate and discuss aspects of the jungles of medical practice, education or administration, please note that all are over-topped by a striking object, the patient. This object must ever be kept in focus. We must never allow his image to become blurred. The formula "What is best for the patient ?" is the touchstone we can and should apply to all of these problems and to their solutions.'

An outstanding, brilliant medical man has left us, but mankind has benefited from all that he was able to do and to achieve.

$\mathrm{He}$ is survived by his wife, daughter and son-in-law and grandchildren.

PHILliP HARRIS

\section{LADY GUTTMANN}

THE many friends of Else Guttmann will have heard with great sadness of her death after a long, lingering illness following a motor accident in April 1972.

Lady Guttmann had a warm and generous personality, and in every way was a wonderful complement to Sir Ludwig. She must have been a great support to him in his life's work in paraplegia. She was a wonderful, loving wife, mother and grandmother and was known all over the world as a charming, witty, intelligent 